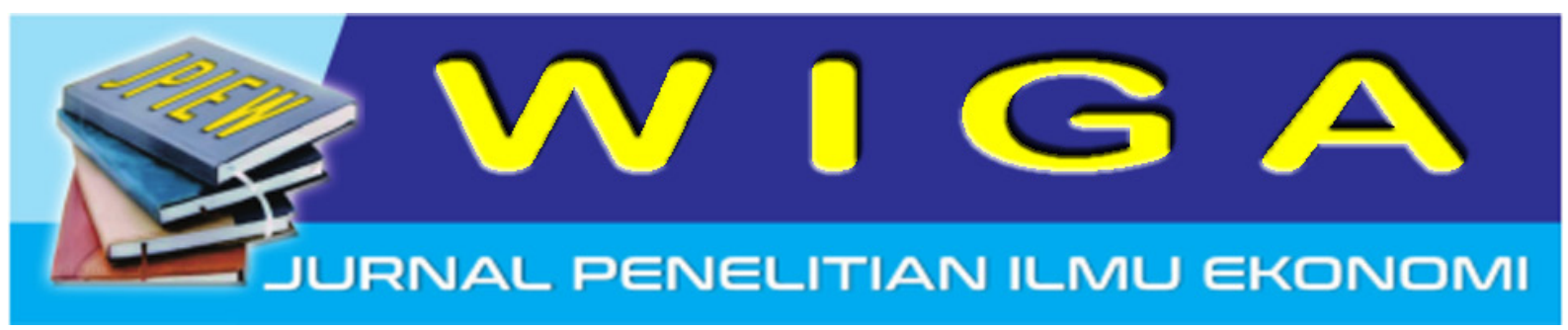

\title{
NILAI KEARIFAN LOKAL KAWASAN WISATA MENGGUNAKAN PENDEKATANGREEN MARKETING BERBASIS MASYARAKAT
}

\author{
Nawangsih \\ STIE Widya Gama Lumajang \\ lovinawang@gmail.com
}

\begin{abstract}
ABSTRAK
Tujuan penelitian untuk mengetahui tentang : bentuk nilai kearifan lokal di kawasan wisata sebagai daya tarik wisata, aplikasi pendekatan green marketinguntuk pelestarian nilai kearifan lokal di kawasan wisata, objek wisata pendukung yang potensial dikembangkan di kawasan wisata menggunakan pendekatan green marketing dan peranan POKDARWIS dalam melestarikan kawasan wisata.Penelitian yang dilakukan menggunakan metode kualitatif dengan pendekatan fenomenologi yaitu sebuah pendekatan dengan melihat keunikan atau fenomena tertentu yang terjadi di kawasan wisata, metode pengumpulan data menggunakan metode wawancara, observasi/pengamatan dan teknik studi dokumen.Hasil penelitian menunjukkan bahwa nilai kearifan lokal dari kawasan wisata tersebut baik dalam bentuk tradisi, adat istiadat menjadi hal yang penting, karena mampu memberikan daya tarik tersendiri. Pendekatan green marketing menjadi salah satu tindakan kongkrit dalam menjaga dan melestarikan konsep kearifan lokal di kawasan wisata yang terkenal sebagai wisata edukasi dan konservasi berwawasan lingkungan, sehingga keberadaan bambu sebagai icon andalan kawasan wisata tetap terjaga kelestariannya dan bermanfaat bagi lingkungan dan masyarakat sekitar.keberadaan obyek pendukung lain di kawasan wisata memberikan nilai tambah sebuah lokasi wisata. Keterlibatan masyarakat sekitar yang perduli terhadap potensi dan obyek wisata dalamKelompok Sadar Wisata / POKDARWIS turut berkontribusi dalam keberhasilan kegiatan green marketing serta kegiatan pelestarian nilai kearifan lokal dari kawasan wisata tersebut
\end{abstract}

Kata kunci : Nilai kearifan lokal, kawasan wisata hutan bambu, green marketing

\section{ABSTRACT}

The research goal is to knowing about: value of local wisdom preserved in the tourist area as a tourist attraction, application of the approach of green marketing in an effort to preserve the value of local wisdom in the tourist area, attraction other potential supporters developed in the tourist area with green marketing approach and role of POKDARWIS to preserve the tourist areas. This study uses a qualitative method using a phenomenological approach. There is the approach with the special characteristic that happen in this location bamboo forets, using interviews, observation / observation and document research techniques.The research results are expected value of local wisdom is like traditions, customs owned by the community can be preserved. Green marketing approach serves as activity to keeping concept of local wisdom in the tourist area as environmentally sound educational of bamboo it can be exis and then can be iconic this location always good and useful to enviroinment and society arroun this place. Kelompok Sadar Wisata / POKARWIS give the contribute to bring a succesthe green marketing activity and the activity to be serve of the value local wisdom from the environmental concern

Keywords : Value of local knowledge, the tourist area of bamboo forest, green marketing 


\section{PENDAHULUAN}

Perkembangan teknologi dalam komunikasi dan informasi (Information Communication and Tecnologi) telah meningkatkan aliran modal, investasi, barang dan jasa dari suatu negara ke negara lain dari negara maju ke negara-negara berkembang pada umumnya. Era dimana dunia tanpa batas dikenal dengan istilah globalisasi.Keberadaan globalisasi membuat negara harus memiliki filterisasi agar dampak negatif yang ditimbulkan dari globalisasi bisa diminimalisir.Nilai kearifan lokal menjadi salah satu pilihan strategi untuk meminimalisir dampak negatif globalisasi dan menjadi counter culture dominasi budaya massa yang dikuasai oleh negara-negara maju yang berpengaruh besar terhadap pola pikir dan budaya di negara-negara berkembang.

Daya tarik lokalitas memberikan pemahaman positif bagi tumbuhnya nilai kearifan lokal (local wisdom) dan nilai-nilai kehidupan yang memberi makna pada pola kehidupan dan interaksi sesama mereka.Nilai strategis budaya lokal menjadi sumber inspirasi daerah untuk mengembangkan potensi lokalitas terutama dalam pengembangan kegiatan pariwisata, upaya pelestarian nilai kearifan lokal ini menjadi hal yang penting agar kegiatan pariwisata tidak melupakan nilai budaya dan spirit lokal.

Daya tarik lokalitas salah satunya diwujudkan dalam keberadaan obyek wisata dalam suatu daerah. Objek wisata di berbagai daerah beragam jenisnya, salah satuya objek wisata SDA.Objek wisata jenis ini perlu mendapat perlindungan dan pelestarian sebagai daya tarik wisata potensial untuk mendatangkan kunjungan wisatawan.Wisata alam meliputi obyek dan kegiatan yang berkaitan dengan memanfaatkan potensi SDA dan ekosistemnya, kegiatan rekreasi di alam terbuka yang alami dan dapat memberikan kenyamanan sehingga semakin banyak dikunjungi orang (wisatawan).

Objek wisata alami salah satunya adalah hutan, pemanfaatan hutan secara tidak langsung adalah dengan cara pemanfaatan lingkungan hutan untuk kegiatan wisata. Objek wisata hutan yang layak untuk dijadikan obyek wisata salah satunya berada di Desa Sumbermujur, Kecamatan Candipuro, Kabupaten Lumajang.Kawasan wisata hutan bambu di Desa Sumbermujur merupakan adalah satu dari beberapa kwasan hutan yang masih tersisa di Indonesia dan terjaga kelestariannya.

Nilai keraifan lokal kawasan wisata agar keberadaannya tetap terjaga dapat didukung dengan menggunakan pendekatan green marketing, yaitu suatu usaha strategis guna menciptakan peluang bisnis yang menuntungkan berbasis lingkungan. Konsep green marketing diharapkan mampu menciptakan potensi peluang bisnis baru yang menguntungkan untuk membantu kesejahteraan masyarakat dengan tetap melestarikan dan menjaga lingkungan menjadi fokus utamanya. Konsep green marketing merupakan variasi terminologi dari environmental marketing, ecological marketing, green marketing, sustainable marketing,

Bentuk kepedulian masyarakat dalam menjaga dan melestarikan kawasan wisata dan lingkungan sekitar termasuk bentuk nilai kearifan lokal yang akan menciptakan sinergi yang positif untuk membangkitkan semangat agar kembali mencintai lingkungan dan bangga kepada bangsa dan negara melalui nilai kearifan lokal di dalamnya.

Nilai kearifan lokal di kawasan wisata dilakukan dengan melibatkan peran serta masyarakat secara aktif menjaga dan melestarikan lingkungan melalui kegiatan pariwisata yang berbasis masyarakat. Komunitas masyarakat yang aktif peduli terhadap kegiatan pelestarian kawasan wisata melalui Kelompok Sadar Wisata / POKDARWIS.Keterlibatan Masyarakat yang dalam POKDARWIS adalah sebagai wujud kongkrit tindakan masyarakat yang peduli terhadap kawasan wisata sekaligus potensi Sumber Daya Alam lainnya, sehingga 
lingkungan tetap terjaga dan berjalan dengan baik sesuai dengan fungsinya.

Kawasan wisata khususnnya hutan bambu berfungsi sebagai daerah sumber resapan air, habitat alami flora dan fauna yang bermanfaat bagi lingkungan di sekitarnya. POKDARWISsebagai bentuk komunitas masyarakat yang peduli terhadap kawasan wisata dan lingkungan memposisikan masyarakat bukan sebagai objek, namun juga sebagai subjek dari kegiatan wisata tersebut.

Kegiatan pariwisata berbasis masyarakat sebagaibentuk kegiatan pengembanganpotensi dan keunggulan suatu daerah di daerah pedesaan melalui sektor pariwisata. Kegiatan pariwisata bukan hanya ditujukan untuk menampilkan wisata yang masih alami, melainkan dapat berkontibusi positif terhadap kegiatan konservasi lingkungan dengan melibatkan peran serta masyarakat sebagai pengendali utama dalam pengembangan kawasan wisata tersebut.Hal ini perlu dilakukan karena masyarakatlokal lebih memahami alam dan budaya yang menjadi potensi dan nilai jual sebagai kawasan tersebut sebagai daya tarik wisata, sehingga keterlibatan dari masyarakat menjadi mutlak (Direktorat Jenderal Pengembangan Destinasi Pariwisata Departemen Kebudayaan dan Pariwisata dan WWF Indonesia, 2009).

\section{PERUMUSAN MASALAH}

Perumusan masalah penelitian yang dilakukan adalah sebagai berikut :

1. Bagaimana bentuk nilai kearifan lokal kawasan wisata sebagai daya tarik wisata?

2. Bagaimana aplikasi pendekatan green marketinguntuk melestarikan nilai kearifan lokal di kawasan wisata?

3. Apa saja objek wisata pendukung yang potensial dikembangkan di kawasan wisata dengan menggunakan pendekatan green marketing?

4. Bagaimana peranan POKDARWIS dalam melestarikan kawasan wisata?

\section{TUJUAN PENELITIAN}

Tujuan penelitian yang diharapkan akan tercapai pada penelitian ini, adalah sebagai berikut :

1. Untuk mengetahui bentuk nilai kearifan lokal di kawasan wisata sebagai daya tarik wisata

2. Untuk mengetahui aplikasi pendekatan green marketing dalam upaya melestarikan nilai kearifan lokal di kawasan wisata

3. Untuk mengetahui objek wisata pendukung yang potensial dikembangkan di kawasan wisata dengan menggunakan pendekatan green marketing

4. Untuk mengetahui peranan POKDARWIS dalam melestarikan kawasan wisata

\section{KAJIAN TEORI}

Kearifan lokal sebagai warisan nenek moyang dalam tata nilai kehidupan menyatu dalam bentuk religi, budaya dan adat istiadat.Kearifan lokal adalah cara dan praktik yang dikembangkan oleh sekelompok masyarakat yang berasal dari pemahaman mendalam terhadap lingkungan setempat dan terbentuk secara turun menurun seperti yang dikemukakan oleh Fathiyah dan Hiryanto (2010:120).Kearifan lokal adalahsebuah pengetahuan masyarakat setempat (local knowledge), kecerdasan setempat (local genius), dan kebijakan setempat (local wisdom).

Wujud kearifan lokal ada di dalam kehidupan masyarakat tradisional yang mengenal dengan baik lingkungannya, masyarakat hidup berdampingan dengan alam secara harmonis, memahami cara memanfaatkan sumberdaya alam secara arif dan bijaksana. Kearifan lokal dalam wujud pengelolaan sumberdaya alam dan lingkungan merupakan wujud konservasi masyarakat.

Sumber Daya Alamapabila dikelola secara maksimal menjadi peluang menjadi 
objek pariwisata potensial.Undang-Undang No.10/2009 tentang kepariwisataan, menyebutkan bahwa pariwisata adalah berbagai macam kegiatan wisata dan didukung oleh berbagai fasilitas serta layanan yang disediakan masyarakat, pengusaha, Pemerintah, dan Pemerintah Daerah.

Pariwisata dalam ruang lingkup yang lebih luas dikenal sebagai Resort City yaitu perkampungan kota yang mempunyai tumpuan kehidupan pada penyediaan sarana dan prasarana wisata seperti penginapan, restoran, olah raga, hiburan dan penyediaan jasa tamasya lainnya. Hal ini tidak dapat dipisahkan dari peranan pengelola kawasan wisata dalam menggali potensi serta sumber daya yang unggul dari kawasan wisata tersebut. Semakin menarik dan unik varian/jenis wisata apabila dikelola optimal akan membantu masyarakat dan kehidupan perekonomian masyarakat sekitar.

Jenis objek wisata baru yang diperkenalkan ke publik adalah wisata hutan atau agroforestry, salah satunya hutan bambu. Bambu adalah merupakan produk hasil hutan non kayu yang dekat dengan kehidupan masyarakat umum, karena tanaman bambu termasuk dalam kategori tanaman yang mudah tumbuh di sekeliling kehidupan masyarakat. Bambu termasuk jenis tanaman Bamboidae anggota sub familia rumput, memiliki keanekaragam jenis bambu di dunia sekitar 1250 - 1500 jenis sedangkan Indonesia memiliki hanya $10 \%$ sekitar 154 jenis bambu

Manfaat bambu menurut Rabik, Brwan et all (2009:15) bambu memiliki peranan penting dalam kehidupan masyarakat. Bambu membantu manusia dalam melaksanakan kehidupan sehari-hari antara lain untuk kebutuhan pangan, rumah tangga, kerajinan, kebutuhan hiburan, konstruksi dan adat istiadat.

Manfaat dan keunggulan yang dimiliki bambu apabila dikelola secara baik akan menjadi produk unggulan yang bermanfaat jika didukung dengan menggunakan pendekatan green marketing. American Marketing
Association (AMA) mendefinisikan green marketing adalah suatu proses pemasaran produk-produk yang diasumsikan aman terhadap lingkungan. Green marketing bukan sekedar menawarkan produk ramah lingkungan, melainkan juga proses produksi, pergantian packaging, serta aktivitas modifikasi produk. Polonsky dalam Sumarwan et all. (2012:216) menyebutkan bahwa green marketing tidak hanya sekedar memasarkan produk ramah lingkungan, tetapi menuntut adanya suatu reorientasi dan tanggung jawab lingkungan dari keseluruhan area, aktivitas, dan departemen dari suatu organisasi.Tujuan green marketing bukan hanya dari sisi keuntungan sebagai tujuan utama perusahaan melainkan juga kepedulian terhadap lingkungan hidup.

Lozada, et all dalam Haryadi (2009:35) menyebutkan bahwa perusahaan akan memperoleh solusi pada tantangan lingkungan melalui strategi marketing, produk, dan pelayanan agar dapat tetap kompetitif. Hal ini dilakukan termasuk pada: teknologi baru untuk menangani limbah dan polusi udara, standarisasi produk untuk menjamin produk yang ramah lingkungan, menyediakan produk yang benar-benar alami dan orientasi produk lewat konservasi sumber daya dan yang lebih memperhatikan kesehatan.

Keunggulan green marketing dibandingkan dengan yang lain adalah konsep green marketingturut melibatkan kepedulian masyarakat terhadap lingkungan sebagai fokus utama kegiatan yang dilakukan, bukan terbatas pada profit/keuntungan produk atau pelayanan yang diberikan kepada konsumen.

Konsep pendekatan menggunakan green marketingmemberikan pemahaman baru agar bisa berinovasi dan berkreasi menciptakan strategi pemasaran baru dengan hasil ganda, yaitu profit dan kepedulian terhadap lingkungan.Hal ini dilakukan untuk memberikan pengetahuan dan pemahaman baik bagi produsen maupun konsumen agar peduli terhadap kelestarian lingkungan sekitar. 
Pendekatan green marketingsecara tepat dapat digunakanuntuk memasarkan kawasan wisata dengan melibatkan semua pihak untuk bekerja sama dan bersinergi termasuk dengan masyarakat sekitar, melaluiPOKDARWIS

\section{METODE PENELITIAN}

Metode penelitian yang digunakan adalah metode kualitatif, menggunakan pendekatan fenomenologi.Fenomena menarik penelitian adalah keberadaan kawasan wisata hutan bambu di Desa Sumbermujur, Kecamatan Candipuro, Kabupaten Lumajang.Teknik pengumpulan data menggunakan wawancara, observasi dan tekhnik studi dokumen. Data hasil penelitian diolah menggunakan snowball sampling untuk dilakukan trianggulasi data guna mendapatkan data hasil penelitian yang valid dan reliabel, sehingga keabsahan data dari kegiatan penelitian yang dapat dipertanggung jawabkan kebenarannya.Informan penelitian terdiri dari : Kepala Bagian Informasi Dinas Pariwisata Kabupaten Lumajang, Kaur Pemerintahan Desa Sumbermujur, pedagang dan wiatawan yang berkunjung ke kawasan wisata hutan bambu

\section{HASILDAN PEMBAHASAN \\ HASIL PENELITIAN}

Hasil kegiatan wawancara di lapangan menunjukkan nilai kearifan lokal kawasan wisata dilestarikan melalui adat istiadat, kesenian, dan lain-lain. Nilai kearifan lokal di kawasan wisata hutan bambu, antara lain: sebagai sarana edukasi dalam bentuk konservasi lingkungan melalui usaha penanaman bambu di kawasan wisata hutan bambu. Tradisi upacara dalam suroan (peringatan 1 Muharram), kesenian jaran kencak, reog, jaran slining dan ruwatan semeru yang digelar secara rutin setiap tahunnya.Kegiatan penanaman padi menggunakan aturan pranoto wongso/aturan bercocok tanam padi menggunakan perhitungan atau aturan tertentu, yaitu dalam 1 tahun penanaman diberikan aktu 2 bulan untuk lahan garapan beristirahat untuk tidak ditanami, hal ini dilakukan untuk menjaga agar tingkat seburan tanah dan kesempatan bagi lahan garapan untuk melakukan perbaikan setelah penanaman dilakukan sebelumnya.Setiap malam satu suro atau 1 Muharram ada semacam tradisi dalam bentuk ritual memendam kepala sapi di kawasan wisata hutan bambu, sebagai wujud rasa syukur dan harapan agar sumber mata air tidak kering, dan debit air meningkat, sehingga mampu memenuhi kebutuhan warga masyarakat sekitarberkaitan dengan ketersediaan pasokan air bersih, irigasi lahan pertanian dan pemanfaatan air bersih untuk kebutuhan lainnya.Upaya pelestarian sumber mata air di kawasan wisata hutan bambu, membutuhkan perhatian semua pihak agar keberadaan sumber mata air dapat dipertahankan, termasuk pelestarian fauna endemik (kalong dan kera) di kawasan wisata tersebut.Keberadaan fauna endemik menjadi daya tarik tersendiri dari kawasan wisata tersebut, sehingga agartidak mengganggu masyarakat sekitar ketika cadangan makanan berkurang, maka kebutuhan cadangan makanan harus tersedia secara cukup.Fauna endemik kawasan wisata mampu menjadi pendukung dan nilai tambah positif karena bermanfaat sebagai hiburan sekaligus sarana belajarterutama berkaitan dengan pelestarian fauna. Nilai kearifan lokal di kawasan wisata dapat maksimal dengan dukungan semua pihak untuk bersinergi dan bekerja sama secara aktif membantu memaksimalkan potensi yang dimilikinya, dalam bentuk kelengkapan sarana dan prasarana kawasan wisata agar kedepannya mampu dijadikan sebagai desa wisata.

Hasil kegiatan wawancara menunjukkan penerapan pendekatan green marketinguntuk melestarikan nilai kearifan lokal di kawasan wisata dapat dilakukan dengan cara : menjadikan hutan bambu sebagai wisata edukasi, mengelola dan menciptakan kawasan sekitar hutan bambu menjadi sektor kegiatan pertanian berbasis organik atau semi organik 
dengan memanfaatkan air dari sumber mata air.melakukan sosialisasi gerakan peduli lingkungan melalui kegiatan pembentukan bank sampah selain untuk menambah pendapatan masyarakat sekaligus juga untuk kebersihan lingkungan khususnya bagi masyarakat yang bertempat tinggal di sekitar lokasi tersebut serta melakukan usaha pembudidayaan aneka jenis tanaman bambu khususnya jenis tanaman bambu endemik asli dari kawasan tersebut agar keberadaan bambu sebagai icon utama daerah tersebut tidak punah serta untuk menjadi sarana pendidikan dan konservasi dengan konsep berwawasan lingkungan.Pendekatan green marketing memberikan ruang untuk terciptanya inovasi objek wisata potensial dengan mengedepankan kepedulian terhadap lingkungan sebagai nilai jual (selling point) yang menjadi pembeda dengan kawasan wisata lainnya. Upaya menumbuhkan kepedulian lingkungan diwujudkan dalam tindakan: membuang sampah pada tempatnya, menumbuhkan rasa peduli lingkungan, rasa bangga sebagai warga desa dengan potensi desa yang dimiliki sekaligus memanfaatkan potensi yang dimiliki melalui kreatifitas dan inovasi untuk menjadikan kawasan wisata hutan bambu sebagai icondestinasi wisata andalan.

Hasil kegiatan wawancara mendapatkan informasi menarik, yaituadanya potensi wisata pendukung lainnya di Desa Sumbermujur, melalui kegiatan pemetaan (mapping) kawasan wisata dari beberapa lokasi andalan.Permasalahan di lapangan yang ditemukan adalah :keberdaan potensi wisata menarik masih belum dikelola maksimal karena pemahaman masyarakat terhadap potensi dari obyek wisata yang baru ditemukan masih kurang. Potensi wisata adalah asset bagi daerah,sehingga apabila dikelola dan dikembangkan mampu menciptakan peluang usaha dan pendapatan bagi masyarakat sekitarnya.

$\begin{array}{lrrr}\text { Hasil } & \text { kegiatan } & \text { wawancara yang } \\ \text { dilakukan berkiatan } & \text { dengan } & \begin{array}{r}\text { kegiatan } \\ \text { pemberdayaan }\end{array} \\ \text { melalui }\end{array}$

POKDARWIS,menunjukkan bahwa kesadaran masyarakat terhadap pelestarian SDA dan pelestarian nilai kearifan lokal telah dilakukan sebelum POKDARWIS terbentuk. Hal ini sebagai bukti kongkrit bahwa masyarakat memahami peran penting lingkungan dalam kehidupan mereka. Hasil temuan di lapangan menunjukkan bahwa selama ini terdapat masalah terutama manajemen pengelolaan POKDARWIS yang pengelolaannya masih belum maksimal,sehingga terjadinya stagnan atau vakumnya organisasi tersebut karena ada permasalahan internal organisasi.

\section{PEMBAHASAN}

Hasil pembahasan berkaitan nilai kearifan lokal di kawasan wisata sebagai daya tarik wisata menunjukkan bahwa upaya menjadikan kawasan wisata hutan bambu sebagai wisata edukasi sangat tepat, kerja sama semua pihak untuk pelestarian kawasan hutan bambu penting dilakukan, misalnya : pembudidayaan bibit bambu agar tetap lestari keberadaannya, pengembangan plasma nutfah agar habitat bambu sebagai icon unggulan tetap terjaga, pelestarian sumber mata air di kawasan wisata hutan bambu melalui manajemen pengelolaan air dilakukan secara bijak agar asset daerah ini bisa dinikmati secara adil dan merata bagi semua pihak.Upaya penanaman tanaman produktif untuk menjaga ketersediaan cadangan makanan bagi fauna endemik di kawasan wisata hutan bambu juga harus dilakukan agar keberadaan fauna tersebut tetap terjaga kelangsungan hidupya dan tidak menganggu kehidupan warga masyarakat sekitar yang tinggal di kawasan hutan bambu.

Pelestarian nilai kearifan lokal di kawasan wisata hutan bambu akan berhasil dengan didukung oleh pendekatan green marketing yaitu upaya memasarkan potensi daerah dengan konsep berwawasan lingkungan. Pengelolaan secara baik asset dan potensi daerah di kawasan wisata hutan bambu sebagai icon dari Desa Wisata Sumbermujur,dapat bermanfaat 
sebagaipeluang menambah pendapatan masyarakat melalui usaha kreatif dan inovatif yang menguntungkan misalnya : masyarakat menciptakan peluang produk industri kreatif dengan membuat kerajinan, produk kuliner atau menjual cemilan dan makanan kecil dengan produk daerah sebagai unggulan, sehingga diharapkan masyarakat memiliki peluang usaha produktif dengan memanfaatkan potensi daya tarik kawasan wisata hutan bambu. Melengkapi fasilitas, sarana dan prasarana di kawasan wisata agar menarik, lebih layak dan menunjang daya tarik potensi wisata di daerah tersebut.

Hasil kegiatan penelitian menunjukkan penerapan pendekatan green marketing dalam upaya melestarikan nilai kearifan lokal di kawasan wisata diwujudkan dalam bentukwisata edukasi, menciptakan kawasan sekitar hutan bambu kegiatan pertanian berbasis organik atau semi organik dengan memanfaatkan air dari sumber mata air sumber delling sebagai air untuk irigasi lahan pertanian. Sosialisasi gerakan peduli lingkungan melalui pembentukan bank sampah dan melakukan pembudidayaan aneka jenis tanaman bambu untuk keperluan penelitian dan konservasi sehingga hutan bambu akan berfungsi secara lebih maksimal sebagai daerah resapan akhir serta menjadi Desa Sumbermujur dengan icon unggulan hutan bambu sebagai desa wisata potensial di Kecamatan Candipuro.Pendekatan green marketing akan memberikan ruang terciptanya inovasi pilihan objek wisata potensial berwawasan lingkungan sebagai nilai jual (selling point) yang menjadi pembeda dengan kawasan wisata lainnya. Kawasan wisata hutan bambu memiliki keunikan yang tidak dimiliki daerah lain. Kerja sama dengan berbagai pihak adalah awal yang baik untuk proses transfer ilmu sekaligus belajar cara budidaya bambu yang baik dari daerah yang berhasil dalam mengembangkannya terlebih dahulu.Keberadaan kawasan wisata hutan bambu menjadi alternatif menciptakan peluang usaha produktif untuk membantu perekonomian masyarakat sekitar kawasan wisata hutan bambu.

Hasil penelitian menunjukkan bahwa potensi wisata pendukung yang layak untuk dikembangkan di kawasan wisata hutan bambu salah satunya melalui melalui pemetaan (mapping) kawasan wisata dari beberapa lokasi andalan yang memiliki potensi unggulan untuk dijadikan tujuan wisata baru.Pemetaan (mapping) lokasi wisata dengan ciri khasnya akan membantu memaksimalkan potensi yang dimiliki. Misalnya kegiatan pemasaran untuk menghasilkan komoditas pertanian organik, kegiatan pembentukan bank sampah, selain untuk keberhasihan juga menjadi peluang tamabahan pendapatan bagi masyarakat.Budidaya tanaman bambu sebagai peluang usaha melalui kegiatan pemasaran dengan menggunakan konsep pendekatan green marketing.Upaya memaksimalkan potensi kawasan wisata agar tidak diklaim atau diakui daerah lain dapat diperkuat secara legalitas melalui kebijakan atau peraturan yang mendukung terkait dengan pariwisata mutlak diperlukan sebagai landasan payung hukum sehingga potensi pariwisata yang dimilikinya terlindungi keberadaannya. Perlindungan hukum dilakukan untuk mencegah tindakan penyalahgunaan hukum.

Hasil kegiatan wawancara berkaitan dengan POKDARWIS memberikan gambaran berkaitan dengan kesadaran dari masyarakat sebelumnya untuk peduli terhadap lingkungannya sudah terbentuk sebelum POKDARWIS dicanangkan.POKDARWIS adalah wadah kepedulian masyarakat dalam menjaga lingkungan sekaligus berkontribusi secara aktif dalam kegiatan peduli lingkungan di kawasan wisata tersebut, melakukan kegiatan sosilisasiprogram peduli lingkungan agar memberikan manfaat positif, sekaligus pembelajaran bagi daerah lain yang tertarik untuk mengembangkan konsep pemasaran dalam bidang yang sama, di daerah mereka.Informasi menarik yang ditemukan adalah tata cara atau manajemen pengelolaan POKDARWIS. Kegiatan sosialisasi termasuk 
menentukan strategi yang tepat agar konsep yang direncanakan oleh pemerintah agar dapat diaplikasikan dengan baik di lapangan.Kebijakan pemerintah membutuhkan pengawasan dan evaluasi dengan melihat kondisi di lapangan untuk mengetahui hasil implementasi akutual dari program yang sudah direncanakan, sehingga dapat dievaluasi agara konsep POKDARWIS dapat menjadi sebuah program yang berkelanjutan dapat tercapai sesuai dengan yang diharapkan. Diperlukan inovasiyang menarik agar mudah diaplikasikan, dan semua pihak yang terlibat memahami peranan pariwisata dalam membantu perekonomian daerah serta sebagai potensi andalan daerah.

\section{KESIMPULAN}

Berdasarkan hasil kegiatan penelitian dan pembahasan yang telah dijelaskan sebelumnya, maka dapat diambil kesimpulan sebagai berikut :

1. Nilai kearifan lokal di kawasan wisata sangat beragam antara lain : upacara seremonial dalam bentuk pemendaman kepala sapi sebagai simbolisasi rasa syukur dengan harapan sumber mata air alami (sumber dhelling) di kawasan wisata hutan bambu akan terus melimpah dan mencukupi kebutuhan warga sekitar. Pelestarian habitat asli dari fauna endemik kawasan wisata hutan bambu yaitu kera dan kalong serta burung punglor merah menjadi hal penting agar kondisi alam tetap lestari

2. Aplikasi pendekatangreen marketing dalam upaya melestarikan nilai kearifan lokal di kawasan wisata diwujudkan dalam bentuk : menjadikan hutan bambu sebagai wisata edukasi, menciptakan kawasan sekitar hutan bambu untuk kegiatan pertanian berbasis organik atau semi organik, sosialisasi gerakan peduli lingkungan melalui bank sampah dan budidaya aneka jenis bambu untuk keperluan penelitian dan konservasi hutan bambu.
3. Objek wisata pendukung yang potensial dikembangkan di kawasan wisata dengan menggunakan pendekatan green marketing, dilakukan melalui :Kegiatan pemetaan (mapping) kawasan wisata beberapa lokasi andalan yang memiliki potensi unggulan untuk dijadikan tujuan wisata sekaligus sebagai peluang usaha produktif untuk menambah pendapatan dari masyarakat setempat.

4. Peranan POKDARWIS dalam melestarikan kawasan wisata adalah berkaitan dengan manajemen pengelolaan POKDARWIS yang belum berjalan secara optimal sesuai dengan yang diharapkan.Sehingga diperlukan inovasi yang menarik, mudah untuk dipalikasikan agar konsep yang disepakati mudah diaplikasikan dan semua pihak

\section{DAFTAR PUSTAKA}

Buku Pedoman Kelompok Sadar Wisata Kabupaten Lumajang Tahun 2014

Fathiyah, K.N. dan Hiryanto. (2013). Local Wisdom Identification on Understanding Natural Disaster Sign by Elders in Daerah Istimewa Yogyakarta : Media Informasi Penelitian Kesejahteraan Sosial. Vol.37, No.1, Maret 2013, hal.453-462.

Francis Wahono. (2005). Pangan, Kearifan Lokal dan Keanekaragaman Hayati, PT. Cinderalas Pustaka Rakyat Cerdas : Yogyakarta

Haryadi, Rudi. (2009). Pengaruh Strategi Green Marketing Terhadap Pilihan Konsumen Melalui Pendekatan Marketing Mix. Tesis tidak Dipublikasikan. 
Peraturan Desa Sumbermujur No. 06 Tahun 2007 Tentang Alam Desa Sumbermujur Lestari dan Berkelanjutan

Peraturan Desa Sumbermujur No. 05 Tahun 2012 Tentang Tata Ruang Desa

Peraturan Desa Sumbermujur No. 07 Tahun 2014 Tentang Generasi Masa Depan yang Mencintai Budaya Seni Tradisional Daerah

Rabik, Brwan et all. 2009. Manajemen pengelolan bambu lestari. PT. Adi Buana : Jakarta.

Sumarwan, Ujang ett all.2012. Riset Pemasaran dan Konsumen, Seri 2. Bogor: PT Penerbit IPB Press

Rabik, Brwan et all. 2009. Manajemen pengelolan bambu lestari. PT. Adi Buana : Jakarta.

Sinaga, Supriono. 2010. Potensi dan Pengembangan Objek Wisata Di Kabupaten Tapanuli Tengah. Kertas Karya. Program DIII Pariwisata. Universitas Sumatera Utara

\footnotetext{
Undang-Undang Nomor 90 Tahun 1990 tentang Pariwisata

Undang-Undang No.10/2009 tentang Kepariwisataan
} 